du Vendômois au goût d'un nouveau public mondain. Dans le même esprit, Marie de Gournay défend Ronsard avec tant d'acharnement qu'elle n'hésite pas à truquer l'un de ses poèmes en faisant croire que c'est une version remaniée laissée par le poète alors qu'elle l'a elle-même mise au goût du jour (M.-C. Thomine-Bichard). Plus tard, La Bruyère se souviendra sans doute des sonnets satiriques de Du Bellay dans ses Caractères, même si sa retenue s'apparente plus à la manière d'Horace qu'à la vitupération de Juvénal (B. Périgot). Enfin, l'on apprend que le discrédit relatif qui pèse encore aujourd'hui sur l'œuvre de Baif est en voie de disparaître ; c'est du moins ce que nous laisse espérer l'édition critique en cours de publication (Jean Vignes).

L'ouvrage se termine par une invitation à aller puiser dans les puissantes ressources de l'internet pour se rendre compte, s'il en est encore besoin, de la "popularité » de Du Bellay aujourd'hui. Aux nombreux exemples que nous présente Yvonne Bellenger, on nous permettra d'ajouter le site astucieusement intitulé « Lyre entre les lignes » qu'un seizièmiste américain a établi pour faire entendre le fameux sonnet d'Ulysse chanté par Ridan avec une coda originale d'une quinzaine de vers (http://www.laits.utexas.edu/rbtl/). On ne pouvait mieux terminer ce beau volume d'hommage au professeur Takata, lui qui a mieux que personne contribué à faire connaître la poésie de la Pléiade hors de France.

FRANÇOIS RIGOLOT, Princeton University

\title{
Bergin, Joseph.
}

Church, Society and Religious Change in France 1580-1730.

New Haven: Yale University Press, 2009. Pp. xvii, 506. ISBN 978-0-300-15098-8 (hardcover) n.p.

In this book the author undertakes the Herculean task of tracing the institutional history of the French Church (writ large - in all of its many facets) during the century-and-a-half between the end of the Religious Wars and the emergence of the Enlightenment. As if that labour were not enough in itself, the author also undertakes an analysis of the impact of institutional changes within the church upon French society. If anyone is qualified to deliver on such a promise 
it is Joseph Bergin, whose earlier studies of Cardinal Richelieu and the French episcopate have elucidated crucial aspects of French religious history in the seventeenth century. Presented here is a mature work of synthesis that will be of great value for historians seeking to understand the nature and process of religious change in France during the siècle des saints.

The book is divided into five parts. The first, "Foundations," has two chapters that provide a geographic and economic overview of the French church in the period. The second part, entitled "Clerical Worlds in Context," offers a chapter each on secular clerics and mendicant orders. Two further chapters in this part deal respectively with the growth of congregations (like the Oratorians, Congregation of the New Mission, and Saint-Sulpice) and women regulars (like the Ladies of Charity and the Daughters of the Congregation of the Mission). Part Three, "A New Clergy?", opens with a chapter on the French episcopate (a topic upon which Bergin is an expert), followed by another on the secular clergy. Both chapters trace long-term changes in these offices. In a third chapter in this section, Bergin challenges the notion that the post-Tridentine push to make the parish the central focus of religious life was realized in France during this period, and calls for a nuanced view that pays more attention to regional diversity and local circumstances. Part four, "Instruments of Religious Change," is divided into four chapters that deal with changes in religious practices: the cult of the saints, the sacraments, the style and content of religious education, and forms of spirituality.

The fifth and final part, aptly titled "Movers and Shakers," moves beyond the realm of the institutional church to discuss the role of confraternities, dévots, and dissident Jansenists in religious change. In these chapters, there is a refreshing shift away from institutions to people, making this the liveliest part of the book. While Bergin sees the growth of confraternities as the "best evidence we have that the Catholic Reformation did read down into French village society" (p. 365), he also emphasizes that Trent had little influence on their devotional agendas, which remained bound to their late-medieval roots. In the chapter on the dévots, Bergin emphasizes the critical important role "pious and militant" (Bergin's translation of dévots) lay people played in the spread of the Catholic reformation. In a final chapter on Jansenism, Bergin argues that in its militant stance, this dissenting movement ultimately aided efforts to reform the church. 
This book owes much to what we might call the "Braudelian" Annales School tradition. From its obligatory opening chapter on historical geography, to its focus on structures and conjunctures, Bergin offers us a portrait of histoire immobile, a type of history where the pace of change is incredibly slow. In fact, the emphasis on "religious change" in the title is slightly ironic; the main focus in the book is on continuity. Some readers will welcome this approach to the so-called 'long seventeenth century' in France, and see in this analysis of the structure of the church broadly conceived as a necessary synthesis - one that allows us to see, in a new light, the almost imperceptible changes to the French church over the course of 150 years. Others, however, more attuned to cultural analysis, micro-history, and narrative, may well find the book somewhat old fashioned and difficult to penetrate. Nonetheless, it is at their own peril that they ignore the keen and nuanced analysis presented in this book.

MARK CRANe, Nipissing University

\section{Buchanan, Georges.}

Poetic Paraphrase of the Psalms of David. Edited, translated, and provided with introduction and commentary by Roger P.H. Green.

Genève: Droz, 2011. 640 p. ISBN 978-2-600-01445-8 (relié) $138 €$

La traduction en vers du Psautier est une des grandes affaires poétiques de la Renaissance, tant en langue vulgaire qu'en néo-latin. Dans cette dernière sphère, les vers offerts par l'écossais Georges Buchanan occupent à n'en pas douter une place peu ordinaire, ne serait-ce qu'en raison du succès éditorial qui fut le leur, assez unique pour ce type de composition. Ils font aujourd'hui l'objet d'une édition par Roger Green dont on connaissait déjà les travaux sur ce texte.

Après avoir souligné dans sa préface la dimension poétique de cette paraphrase - une telle position module sensiblement un regard plus souvent porté sur le caractère paraphrastique de ces vers -, Green propose une introduction qui expose finement les principaux éléments de réflexion sur le texte. En premier lieu viennent les conditions d'écriture d'un poème latin où se croisent source biblique et intérêt pour les formes poétiques horatiennes. S’il reste difficile de proposer une date d'amorce de la composition, la captivité du 